\title{
PENANGGULANGAN DAN PENCEGAHAN TUBERKULOSIS SEBAGAI PENERAPAN DAKWAH BILHAL 'AISYIYAH SURABAYA
}

\author{
Muhammad Hildan Azizi dan Anggit Rizkianto \\ STID Al-Hadid, Surabaya dan Pascasarjana UIN Sunan Ampel, Surabaya \\ hildanazizi@gmail.com dan anggitrizkianto@gmail.com
}

\begin{abstract}
Abstrak: Studi ini dilatarbelakangi oleh aktivitas dakwah 'Aisyiyah Surabaya, yang sejak pertengahan tahun 2014 memprioritaskan dakwahnya melalui dakwah bilhal, yaitu dakwah dengan tindakan nyata yang berorientasi perbaikan masalah masyarakat. Dakwah bilhal yang menjadi fokus kajian dalam studi ini adalah program penanggulangan dan pencegahan TB yang telah membuahkan hasil positif. Studi ini bertujuan memaparkan secara komprehensif pelaksanaan dakwah bilhal oleh 'Aisyiyah Surabaya. Pendekatan yang digunakan adalah kualitatif dan datanya didapatkan dari dokumentasi, observasi partisipatif serta wawancara mendalam. Penentuan narasumber dilakukan secara purposive sedangkan analisis melalui tahap mereduksi, mengorganisasikan serta menyajikan (display) data. Hasil penelitian menunjukkan 'Aisyiyah Surabaya sebagai subjek dakwah melakukan dakwahnya dengan hikmah dan keteladanan dengan pesan dakwah tentang kepedulian sosial kepada semua masyarakat Surabaya tanpa terkecuali sebagai mad'uw, dengan media yang cukup efektif dan efisien. Dakwah bilhal tersebut secara kedudukan untuk melengkapi dakwah lisan yang telah dilakukan. 'Aisyiyah Surabaya juga mengajak umat memahami masalah, menumbuhkan keinginan umat untuk berperan aktif, melibatkan umat dalam pelaksanaan pemecahan masalah, menyebarkan metode swadaya umat dan adanya evaluasi serta tindak lanjut dengan melibatkan umat. Hal yang perlu dikembangkan adalah meningkatkan tingkat partisipasi masyarakat dalam pengambilan keputusan atas solusi pemecahan masalah.
\end{abstract}

Kata Kunci: dakwah bilhal, 'Aisyiyah, tuberkulosis

\begin{abstract}
This study is grounded in da'wah activities of 'Aisyiyah Surabaya, which has prioritized its propagation / da'wah through da'wah bilhal since the mid of 2014. Da'wah bilhal means a propagation conducted by doing a real effort aiming to solve a social problem. Da'wah bilhal becoming the focus on this study is a program of overcoming and preventing tuberculosis which has yielded a positive result. This study aims to comprehensively explain about da'wah bilhal implementation of 'Aisyiyah Surabaya. The approach of study used is qualitative and its data are obtained from documentation, participative observation and in-depth interview. The selection of resources was conducted purposively while its analysis was examined through the phases of reducing, organizing and displaying data. The result of study indicates 'Aisyiyah Surabaya, as a subject of da'wah (mad'uw), has propagated wisdom and good example with da'wah message on social care for the society of Surabaya in effective and efficient media. Based on its position, da'wah bilhal is conducted to complete verbal propagation done previously. 'Aisyiyah Surabaya also asked people to understand a problem, grow their active participation, be involved in dealing with problem solving, share people's self supporting method and evaluate and do follow-up by involving people. The ones which
\end{abstract}


need to be developed are to improve the level of people's participation in taking a decision on solution.

Keywords: Da'wah bilhal, 'Aisyiyah, Tuberculosis

\section{Pendahuluan}

Pada umumnya dakwah lebih banyak dilakukan dengan pendekatan lisan yang lebih menyentuh aspek kognisi. Dakwah lisan yang membentuk pemahaman akan ajaran agama Islam di kalangan jemaah perlu dipikirkan tindak lanjutnya agar pemahaman tersebut dapat termanifestasikan di lapangan sosial. Oleh karena itu, diperlukan pendekatan dakwah yang berkesinambungan dan terukur. ${ }^{1}$ Artinya seruan dakwah melalui lisan juga perlu diimbangi dengan amal nyata di lapangan sosial yang dapat dilihat secara empiris yang mampu menggerakkan kesadaran sasaran dakwah. Dakwah yang menekankan pada perilaku-perilaku sosial ini disebut dengan dakwah bilhal atau dakwah dengan perbuatan. Dengan demikian dakwah bilhal dapat menjadi alternatif untuk menjawab persoalan-persoalan kontemporer saat ini. ${ }^{2}$

'Aisyiyah Surabaya merupakan organisasi yang cukup konsisten di dalam melakukan dakwah bilhal. Organisasi ini mulai memprioritaskan dakwah bilhal sejak pertengahan tahun 2014, saat 'Aisyiyah Surabaya mulai melaksanakan program penanggulangan dan pencegahan

1 Suisyanto, "Dakwah Bil-Hal (Suatu Upaya Menumbuhkan Kesadaran dan Mengembangkan Kemampuan Jemaah)," Aplikasia, Jurnal Aplikasi IImuilmu Agama, Vol. III, No. 2 (Desember 2002): 183.

2 Ibid.

3 Alifah Hikmawati (Ketua 'Aisyiyah Surabaya), Wawancara oleh Penulis, Surabaya, 19 juni 2017. tuberkulosis (TB) yang terus berlangsung hingga sekarang. ${ }^{3}$ Sebelumnya, 'Aisyiyah Surabaya lebih mengandalkan dakwah lisan dengan majelis tablig sebagai majelis/badan pembantu di bidang dakwah, yang menjalankan berbagai macam program kajian keagamaan. 4 Dakwah bilhal yang diperjuangkan 'Aisyiyah Surabaya hingga sekarang terbukti membuahkan hasil. Total para penderita TB yang sudah ditangani serta dibimbing oleh 'Aisyiyah hingga sembuh dari 12 kecamatan di Surabaya kurang lebih ada 16.000 orang. Kemudian atas dorongan 'Aisyiyah Surabaya, kini peraturan daerah untuk penanggulan TB di kota Surabaya sudah ditetapkan panitia khususnya dan naskah peraturan daerah tengah disusun dan dibahas di DPRD kota Surabaya. Proses penyusunan dan pembahasan peraturan daerah tersebut telah berjalan maksimal, dan dalam waktu dekat akan segera disahkan. ${ }^{5}$ Sebelum itu, 'Aisyiyah Surabaya telah berhasil melakukan advokasi melalui Peraturan Daerah Nomor 2 Kota Surabaya tentang Upaya Kesehatan, perda tersebut juga memudahkan penanggulangan dan pemberantasan TB. ${ }^{6}$

Studi ini hendak menjelaskan secara komprehensif tentang bagaimana penerapan

${ }^{4}$ Ibid.

5 "Aisyiyah Gugah Pemkot untuk Surabaya Bebas HIV dan TB," Situs pwmu.co, 20 Juni 2017, http://www.pwmu.co

${ }^{6}$ Siti Maslamah (Ketua TB Care 'Aisyiyiyah Surabaya), Wawancara dengan Penulis, Surabaya, 26 Desember 2017. 
dakwah bilhal yang dilaksanakan oleh 'Aisyiyah Surabaya. Fokus penelitian lebih mengarah pada penerapan dakwah bilhal 'Aisyiyah Surabaya melalui program penanggulangan dan pencegahan TB sejak pertengahan tahun 2014 hingga tahun 2017, saat itulah 'Aisyiyah Surabaya memprioritaskan gerakan dakwahnya pada dakwah bilhal dalam kurun waktu tersebut, bahkan hingga sekarang. Kajian ini nantinya diharapkan dapat memberikan khazanah baru dalam pengembangan ilmu dakwah, khususnya dakwah dengan perbuatan (bilhal) yang melibatkan lembaga atau organisasi dakwah tertentu. Pada lapangan praktis kajian ini juga diharapkan dapat melengkapi dakwah yang sudah dilakukan selama ini yang umumnya masih menggunakan dakwah dengan pendekatan lisan.

Kajian mengenai dakwah bilhal sejauh ini banyak memfokuskan kajiannya pada aspek moral yang lebih bersifat imaterial, jarang sekali ada yang memfokuskannya pada aspek pemberdayaan secara ekonomi, kesejahteraan, kesehatan, hukum, pendidikan yang lebih bersifat material. Hal ini sebagaimana kajian yang ditulis oleh Astuti Patiminingsih dan Sumarlik yang memfokuskan kajian dakwah bilhal dalam bidang pembinaan keluarga. ${ }^{78}$ Adapun

\footnotetext{
${ }^{7}$ Astuti Patiminingsih, "Strategi Dakwah 'Aisyiyah Dalam Pembinaan Keluarga Sakinah", Jurnal Ilmu Dakwah dan Pengembangan Komunitas, Vol. 9, No. 2 (Juli, 2014), 144 8 Sumarlik, "Aktifitas Organisasi 'Aisyiyah Cabang Wonocolo terhadap Pembinaan Keluarga Sakinah di Kecamatan Wonocolo Kodya Surabaya," (Tesis - UIN Sunan Ampel, Surabaya, 2016), 16.

${ }^{9}$ Chandra Syahputra, "Pengaruh Metode Dakwah Bilhal terhadap Pembinaan Akhlak Remaja Gampong Maurendeh Kecamatan Langsa Lama" (Skripsi - STAIN Zawiyah Cot Kala Langsa, 2013)
}

penelitian yang lain adalah yang diteliti oleh Chandra Syahputra, yang memfokuskan kajian dakwah bilhal-nya dalam bidang pembinaan akhlak remaja. ${ }^{9}$ Begitu pula dengan penelitian yang dilakukan oleh A. Saiful Mu'minin dan Khoirul Umam yang kemudian menganalisis dakwah bilhal dengan seruan atau himbauan perubahan moral atau akhlak. ${ }^{1011}$ Dengan demikian, studi ini diharapkan dapat memberikan perspektif baru dengan memfokuskan kajian dakwah bilhal-nya dalam bidang kesehatan yang dilakukan oleh suatu organisasi dakwah. Kajian ini tentunya tidak lepas dari definisi atau substansi dari dakwah itu sendiri.

\section{Dakwah Bilhal}

Secara etimologi dakwah bilhal merupakan gabungan dari kata dua kata yaitu kata dakwah dan al-Haal. Kata dakwah artinya mengajak, menyeru, memanggil. ${ }^{12}$ Sedangkan kata al-Haal berarti keadaan. Jika dua kata tadi dihubungkan maka dakwah bilhal mengandung arti memanggil, menyeru dengan menggunakan keadaan, atau menyeru dan mengajak dengan keteladanan dan perbuatan nyata. ${ }^{13} \mathrm{Hal}$ ini dimaksudkan agar penerima dakwah mengikuti jejak dan hal ihwal dai (juru dakwah). Dakwah jenis ini mempunyai pengaruh yang besar pada diri

10 A. Saiful Mu'minin, "Konstruksi Simbolik Dakwah Bilhal dalam Film Hafalan Shalat Delisa" (Skripsi - UIN Syarif Hidayatullah, 2014)

${ }^{11}$ Khoirul Umam, "Visualisasi dakwah bilhal dalam film Alangkah Lucunya Negeri Ini" (Thesis - UIN Walisongo, 2016)

${ }^{12}$ Samsul Munir Amin, Ilmu Dakwah (Jakarta: Amzah, 2013), 3.

13 Siti Muru'ah, Metodologi Dakwah Kontemporer (Yogyakarta: Mitra Pustaka, 2000), 75. 
penerima dakwah. Pada saat pertama kali Rasulullah Saw. tiba di kota Madinah, beliau mencontohkan dakwah bilhal dengan mendirikan Masjid Quba dan mempersatukan kaum Anshar dan kaum Muhajirin dalam ikatan ukhuwah Islamiah. ${ }^{14}$

Perlu dipahami bahwa dakwah bilhal bukan hanya menyangkut pendekatan dalam berdakwah, tetapi juga menyangkut paradigma dalam berdakwah. Dakwah bilhal bukan bermaksud mengganti dakwah lisan, tetapi melengkapi dakwah lisan yang sudah ada, karena keduanya mempunyai peran penting dalam proses penyampaian ajaran Islam, isi dakwah yang disampaikan secara lisan akan lebih baik jika seimbang dengan perbuatan nyata dai. ${ }^{15}$ Namun, dakwah bilhal memiliki tantangan dalam penerapannya karena memerlukan keterampilan yang lebih, dan mengeluarkan biaya yang besar. ${ }^{16}$ Ruang lingkup dakwah bilhal meliputi semua persoalan yang berhubungan dengan kebutuhan pokok (basic needs) manusia yang berkaitan dengan kebutuhan fisik/material maupun nonmaterial. Maka kegiatan dakwah bilhal lebih menekankan pada perbaikan/pengembangan kehidupan dan penghidupan masyarakat dalam rangka meningkatkan taraf hidup yang lebih baik sesuai dengan tuntunan ajaran Islam. Bentukbentuk pengembangan kegiatan dakwah bilhal dapat dilakukan melalui bentuk seperti

\footnotetext{
${ }^{14}$ Faizal, "Dakwah Bil-Hal dalam perspektif al-Qur'an", Jurnal Ilmu Dakwah dan Pengembangan Komunitas, Vol. VIII No. 2 (Juli 2013): 3.

15 Soetjipto Wirosardjono, "Dakwah: Potensi dalam Kesenjangan" dalam Majalah Pesantren, No. 4 Vol. IV (Jakarta: P3M, 1987), 5.

16 Asmuni Syukir, Dasar-Dasar Strategi Dalam Islam (Surabaya: Al Ikhlas, 1983), 127.
}

penyelenggaraan pendidikan pada masyarakat, pembangunan koperasi, penyelenggaraan usaha kesehatan masyarakat, peningkatan gizi masyarakat, penyelenggaraan panti asuhan serta penciptaan lapangan kerja ${ }^{17}$ Dalam hal kebutuhan atau kesejahteraan nonmateril, dakwah bilhal yang dapat dilakukan misalnya adalah meningkatkan kualitas pengamalan ibadah serta akhlak. ${ }^{18}$

Setiap dakwah pasti terdapat unsur-unsur di dalamnya, tak terkecuali dakwah bilhal. Unsur-unsur atau hal yang tedapat dalam setiap kegiatan dakwah bilhal antara lain subjek dakwah (dai), objek dakwah (mad'uw), pesan dakwah, metode dakwah, serta media dakwah. Pertama, subjek dakwah merupakan orang yang menyampaikan pesan dakwah, yang umumnya disebut dengan dai. Sehingga penyebutan dai senantiasa merujuk pada orang yang aktif melaksanakan dakwah kepada masyarakat. Dai ini ada yang melaksanakan dakwahnya secara individu ada juga yang berdakwah secara kolektif melalui sebuah organisasi. ${ }^{19}$ Namun untuk dakwah bilhal yang sangat menekankan langkah nyata untuk menyelesaikan masalah yang ada di masyarakat, subjek dakwah semestinya menggunakan kelembagaan atau wadah organisasi. ${ }^{20}$

\footnotetext{
17 Harun Al-Rasyid dkk, Pedoman Pembinaan Dakwah Bil-Hal, 10-14.

18 Suisyanto, "Dakwah Bil-Hal.,"188.

${ }^{19}$ Wahidin Saputra, Pengantar Ilmu Dakwah, (Jakarta: PT. Raja Grafindo Persada, 2012), 8.

20 Moh. Ali Aziz, Ilmu Dakwah, (Jakarta: Kencana, 2004), 381.
} 
Kedua, objek dakwah atau yang disebut juga dengan mad'uw atau adalah masyarakat atau orang yang didakwahi, yakni diajak ke jalan Allah agar selamat di dunia maupun akhirat. Masyarakat sebagai objek dakwah bilhal sangat heterogen, misalnya masyarakat yang berprofesi sebagai petani, nelayan, pedagang, pegawai, buruh, artis, anggota legislatif, eksekutif, karyawan, dan lainnya. Bila melihat dari aspek geografis, masyarakat ada yang tinggal di kota, desa, pegunungan, pesisir bahkan ada yang tinggal di pedalaman. Bila dilihat dari aspek agama, maka mad'uw ada yang berstatus muslim/mukmin, kafir, munafik, musyrik, dan sebagainya. ${ }^{21}$

Ketiga, pesan dakwah di sini senantiasa meliputi isi pesan dakwah atau materi yang disampaikan dai kepada mad'uw. Isi pesan dalam dakwah bilhal sifatnya sangat luas, yang tidak hanya terbatas pada masalah akidah, syariat atau akhlak, tetapi juga dapat terkait masalah ukhuwah, sosial, kemasyarakatan, pendidikan, kebudayaan, serta amar makruf nahi mungkar. ${ }^{22}$ Kemudian Quraish Shihab juga mengatakan bahwa pesan dakwah dapat berupa pemaparan ideide agama atau sumbangan agama yang ditunjukkan kepada masyarakat luas yang sedang membangun, khususnya di bidang sosial, ekonomi, dan budaya. Serta dapat juga berupa tentang pokok agama yang menjadi landasan bersama untuk mewujudkan kerjasama antaragama tanpa mengabaikan identitas masing-masing. ${ }^{23}$

\footnotetext{
${ }^{21}$ Saputra, Pengantar Ilmu Dakwah., 8-9.

${ }^{22}$ Aziz, Ilmu Dakwah., 92.

${ }^{23}$ Quraish Shihab, Membumikan Al-Qur'an (Bandung: Mizan, 1994), 200.

${ }^{24}$ Amin, Ilmu Dakwah., 178.
}

Keempat, metode dakwah. Dalam konteks dakwah bilhal, metode dakwah dengan bil hikmah tentu sangat ditekankan, yakni dengan memperhatikan situasi dan kondisi sasaran dakwah dengan menitikberatkan kepada kemampuan mereka, sehingga mereka tidak merasa terpaksa atau keberatan dalam menerima materi dakwah. Kemudian dakwah diaplikasikan ke dalam berbagai tindakan-tindakan nyata mulai dari mengembangkan/memanfaatkan sumber daya masyarakat, membangun masjid, memberikan pendidikan dan sebagainya. ${ }^{24}$ Namun, yang paling utama adalah pada bagaimana dai memberikan contoh teladan kepada mad'uw atau umat. ${ }^{25}$

Kelima, media dakwah. Media dalam dakwah bilhal dapat diklasifikasikan menjadi dua, yaitu media massa dan media nonmassa. Media massa digunakan dalam dakwah apabila mad'uw berjumlah banyak dan bertempat tinggal jauh. Media massa yang banyak dapat digunakan umumnya surat kabar, radio, televisi, dan film bioskop yang beroperasi dalam bidang informasi dakwah. ${ }^{26}$ Sedangkan media nonmassa digunakan dalam dakwah untuk orang tertentu atau kelompokkelompok (forum) tertentu seperti surat, telepon, SMS, telegram, faks, papan pengumuman, $\mathrm{CD}$, e-mail, dan lain-lain. ${ }^{27}$ Media nonmassa dapat pula berupa mediamedia benda seperti gambar/foto, proyektor, televisi, internet dan sebagainya. ${ }^{28}$ Pada

\footnotetext{
25 Suisyanto, "Dakwah Bil-Hal.," 185.

${ }^{26}$ Wahyu Ilaihi, Komunikasi Dakwah, (Bandung: Remaja Rosdakarya, 2010), 105.

27 Ibid., 106.

${ }^{28}$ Amin, Ilmu Dakwah., 117-120.
} 
prinsipnya benda-benda tersebut dapat mendukung tercapainya pesan dakwah kepada objek dakwah.

Untuk melaksanakan dakwah bilhal yang berorentasi pada perbaikan masalah-masalah yang ada di masyarakat sebagaimana dijelaskan sebelumnya, maka diperlukan beberapa prinsip pelaksanaannya yang antara lain, pertama, mengajak umat/masyarakat untuk mengenali dan memahami masalah mereka sendiri. Masalah yang dialami oleh umat/masyarakat sering tidak dipahami oleh masyarakat itu sendiri. Oleh karena itu dai perlu mengajak umat atau masyarakat untuk memahami dan menyadari akan masalah yang dihadapi; dalam hal ini bimbingan dan penyuluhan merupakan kegiatan yang penting sebagai langkah awal. Untuk langkah lanjutnya adalah bagaimana membangun partisipasi masyarakat, tidak hanya pada tingkat pemahaman tetapi juga pada bagaimana mengorganisasikan masalah tersebut sebagai langkah awal dari pemecahan masalah. Jika ada sikap apatis dan pasrah akibat ketidakberdayaan, di mana mereka telah memahami masalahnya tetapi menganggap bahwa itu tidak mungkin diperbaiki lagi, dai perlu melakukan remotivasi, reorganisasi, dan reedukasi dalam rangka menyadarkan mereka agar ikut berperan aktif kembali di dalam kehidupan, utamanya dalam melihat dan memahami masalah secara proporsional. ${ }^{29}$

Kedua, menumbuhkan keinginan umat/masyarakat untuk berperan aktif.

\footnotetext{
${ }^{29}$ Suisyanto, "Dakwah Bil-Hal.,"190.
}

$30 \mathrm{lbid}$.
Setelah terbentuk pemahaman masalah, maka selanjutnya mencari alternatif pemecahan masalah. Dalam pencarian alternatif ini umumnya umat atau jemaah membutuhkan bantuan dari dai. Dalam hal ini yang perlu dikedepankan adalah kemauan anggota masyarakat untuk ikut andil dalam kegiatan pemecahan masalah yang dapat ditempuh dengan metode partisipatoris. Dengan demikian akan dirasakan bahwa persoalan yang dihadapi umat menjadi milik mereka serta menjadi bagian hidup mereka dan tanggung jawab mereka untuk mencari jalan keluarnya. Dalam situasi seperti ini dai bertindak sebagai fasilitator dan pendamping jemaah. Segala usul kritik dan saran jemaah sebagai subjek, dan bukan objek, disalurkan melalui forum yang disepakati. ${ }^{30}$

Ketiga, pelibatan umat/masyarakat dalam pelaksanaan pemecahan masalah. Setelah jemaah mendapatkan alternatif pemecahan masalah yang dihadapi kemudian bagaimana dai membantu dalam mentransformasikan alternatif dimaksud ke dalam langkah pelaksanaan. Dalam hal ini jemaah dilibatkan secara keseluruhan dalam rencana; memulai, melaksanakan, dan mengevaluasi program kegiatan. Dengan keterlibatan jemaah ini mereka melakukan sesuatu bukan karena perintah tetapi atas dasar kesadaran, kebutuhan dan kewajiban yang pada perkembangan selanjutnya mereka diharapkan dapat mengambil keputusan sendiri untuk memenuhi kebutuhan mereka. ${ }^{31}$ 
Keempat, penyebarluasan metode-metode swadaya umat. Salah satu prinsip penting dalam dakwah bilhal adalah harus mampu mendorong dan menggerakkan kemampuan masyarakat dalam memecahkan masalah. Dengan kata lain dakwah bilhal harus mampu membangkitkan swadaya masyarakat, agar mereka dapat membangun dirinya, sekaligus dapat memberikan manfaat masyarakat sekitarnya. Oleh karena itu seorang dai seharusnya tidak mendidik jemaah menjadi kelompok konsumtif yang pasif tetapi lebih mengarahkan kepada mereka sebagai pekerja aktif. Di sinilah perlunya pengembangan berbagai metode. Sebagai contoh, jika jemaah membutuhkan ikan janganlah mereka diberi ikan tetapi berilah kail, jala atau jaring, ajarilah mereka bagaimana cara mencari ikan dengan alat tersebut. Dan bersama-sama antara dai dan jemaah menelusuri tempat yang banyak ikan. ${ }^{32}$

Kelima, evaluasi dan tindak lanjut. Setiap akhir kegiatan yang telah direncanakan kemudian dievaluasi secara bersama-sama antara dai sebagai fasilitator (pendamping) dengan umat/masyarakat sebagai subjek utama. Evaluasi dimaksudkan sebagai upaya melihat kelemahan dan kelebihan program tersebut untuk kemudian memikirkan rencana berikutnya yang lebih tertata dan bagus. Dengan kata lain selalu dilakukan refleksi dan aksi untuk mendapatkan suatu kerja dakwah yang maksimal. ${ }^{33}$

\footnotetext{
32 Ibid.

33 Ibid., 191.

${ }^{34}$ Sugiyono, Metode Penelitian Kuantitatif Kualitatif Dan $R \& D$ (Bandung: Alfabeta, 2008), 216.
}

\section{Metodologi}

Studi ini menggunakan pendekatan kualitatif dengan penentuan sumber data atau narasumber yang dilakukan secara purposive, yaitu narasumber dipilih berdasarkan pertimbangan dan tujuan tertentu. Narasumber/informan yang ditentukan adalah pihak yang benar-benar mengetahui dan memahami permasalahan penelitian. ${ }^{34}$ Adapun jumlah narasumber dalam studi ini sebanyak tiga orang, mulai dari pimpinan daerah 'Aisyiyah Surabaya sendiri, salah seorang pengurus di tingkat daerah, serta koordinator dari para relawan yang terlibat dalam program penanggulangan TB. Teknik pengumpulan data dilakukan dengan wawancara mendalam terhadap narasumber tersebut, artinya narasumber diberi kebebasan yang seluas-luasnya untuk menyampaikan pendapatnya tentang sesuatu gejala, fenomena dan situasi. ${ }^{35}$ Selain itu, teknik pengumpulan data juga dilakukan dengan teknik dokumentasi serta observasi partisipatif. Teknik dokumentasi dengan menggunakan data-data sekunder yang diperoleh dari dokumen seperti laporan tahunan dan laporan kegiatan. Selain itu pemberitaan di media terkait kegiatan 'Aisyiyah kota Surabaya juga bisa digunakan sebagai data sekunder. Sedangkan observasi partisipatif yang digunakan dalam studi ini adalah partisipatif pasif, artinya peneliti datang ke tempat kegiatan yang sedang diteliti, tetapi tidak ikut terlibat dalam kegiatan tersebut. ${ }^{36}$

\footnotetext{
35 Djam'an Satori, Metode Penelitian Kualitatif (Bandung: Alfabeta, 2010), 130.

${ }^{36}$ Sugiyono, Memahami Penelitian Kualitatif, (Bandung: Alfabeta, 2014), 66.
} 
Data-data yang telah dikumpulkan kemudian diuji kredibilitasnya melalui triangulasi sumber data, dengan melakukan pengecekan data yang didapat dari beberapa sumber, mulai dari para pimpinan hingga pengurus 'Aisyiyah kota Surabaya sendiri, para relawan dari program dakwah bilhal hingga kelompok masyarakat yang menjadi mad'uw dari program dakwah bilhal. Setelah data dikumpulkan dan diuji, kemudian data akan dianalisis mulai dari melakukan reduksi data (data reduction), mengorganisasikan data, serta penyajian data (data display). Dengan demikian, data akan lebih mudah untuk dibaca dan diinterpretasikan.

\section{Profil 'Aisyiyah Surabaya}

'Aisyiyah di Surabaya didirikan pertama kali pada tahun 1961. Secara struktural, 'Aisyiyah Surabaya berkedudukan sebagai Pimpinan Daerah 'Aisyiyah (PDA) di tingkat kota/kabupaten, berada dibawah Pimpinan Wilayah 'Aisyiyah (PWA) di tingkat provinsi serta Pimpinan Pusat 'Aisyiyah (PPA) di tingkat nasional. Secara visi atau tujuan keorganisasian, 'Aisyiyah Surabaya tetap mengikuti visi misi organisasi pusat, yakni tercapainya usaha-usaha Aisyiyah yang mengarah pada penguatan dan pengembangan dakwah amar makruf nahi mungkar secara lebih berkualitas menuju masyarakat madani, yakni masyarakat Islam yang kafah (sebenar-benarnya). ${ }^{37} \mathrm{Di}$ tingkat

\footnotetext{
37 "Visi Misi 'Aisyiyah Surabaya", Situs Aisyiyahsurabaya.sg., 20 Juni 2017, http://aisyiyahsurabaya.sg

${ }^{38}$ Alifah Hikmawati, Wawancara.

$39 \mathrm{lbid}$.
}

daerah kota Surabaya ini, 'Aisyiyah memiliki pengurus sebanyak 85 orang. ${ }^{38}$

'Aisyiyah Surabaya membawahi hampir semua kecamatan dan kelurahan di kota Surabaya, Dari total 31 kecamatan yang ada di kota Surabaya, Aisyiyah sudah memiliki 29 Pimpinan Cabang 'Aisyiyah (PCA). Pada masing-masing PCA rata-rata ada 5-6 ranting, masing-masing ranting memiliki anggota yang berkartu tanda anggota rata-rata 50 orang. ${ }^{39}$ Sehingga jika dikalkulasikan 'Aisyiyah sudah memiliki lebih dari 10.000 anggota di Surabaya (memiliki kartu anggota). Sebagai organisasi kewanitaan dan otonom dari Muhammadiyah yang mengurus rumah tangga organisasinya sendiri, 40 'Aisyiyah Surabaya selama ini memiliki program yang sangat beragam di berbagai bidang. Programprogram itu dilaksanakan melalui berbagai badan pembantu/majelis yang dimiliki 'Aisyiyah yang membidangi urusan tertentu, mulai dari pendidikan, ekonomi, kesejahteraan masyarakat, kesehatan hukum, budaya dan sebagainya. ${ }^{41}$

\section{Dakwah Bilhal Penanggulangan dan Pencegahan TB ‘Aisyiyah Surabaya}

\section{Dasar Pemikiran}

Kepedulian 'Aisyiyah Surabaya terhadap penderita TB dimulai sejak pertengahan tahun 2014, saat itu 'Aisyiyah menetapkan program "Surabaya Zero TB". Upaya penanggulangan

\footnotetext{
40 Adaby Dahlan, 'Aisyiyah dan Sejarah Pergerakan Perempuan Indonesia: Sebuah Tinjauan Awal (Yogyakarta: Jurusan Sejarah FIB UGM, 201 0), 115.

${ }^{41}$ Alifah Hikmawati, Wawancara.
} 
dan pencegahan TB itu dilaksanakan atas dasar semangat dakwah sebagaimana visi misi 'Aisyiyah sendiri, dimana 'Aisyiyah ingin memperbaiki dan membangun kualitas umat, menuju masyarakat Islam yang madani serta kafah (sebenar-benarnya). Program "Surabaya Zero TB" kemudian terus bergulir dan semakin dikembangkan yang juga didorong oleh keputusan Muktamar Muhammadiyah di Makasar pada tahun 2015. Pada muktamar tersebut diputuskan bahwa yang menjadi program unggulan Muhammadiyah adalah di bidang pendidikan, kesehatan serta ekonomi. ${ }^{42}$

Dakwah bilhal yang dilakukan oleh 'Aisyiyah Surabaya juga tidak lantas menghilangkan dakwah lisan yang sudah dilakukan sebelumnya. Kajian kegamaan yang sudah menjadi program 'Aisyiyah Surabaya melalui majelis tablig tetap terus berjalan. Dengan dakwah bilhal, masyarakat semakin mengenal 'Aisyiyah. Tidak sedikit masyarakat yang berhasil sembuh dari penyakit TB karena bantuan 'Aisyiyah Surabaya kemudian menjadi simpatisan dan mengikuti kajian keagamaan yang dilaksanakan oleh Majelis Tablig 'Aisyiyah Surabaya. ${ }^{43}$

\section{Pelaksanaan Dakwah Bilhal 'Aisyiyah Surabaya dalam Penanggulangan dan Pencegahan TB}

'Aisyiyah Surabaya membentuk program "Surabaya Zero TB" sebagai wujud implementasi penanggulangan dan

$42 \mathrm{lbid}$. Lihat juga "Program unggulan Haedar Nashir di Muhammadiyah", dalam: http: //www.berisatu.com (8 september 2017)

${ }^{43}$ Alifah Hikmawati, Wawancara, Surabaya, 9 Agustus 2017. pencegahan TB di kota Surabaya. Program "Surabaya Zero TB" ini kemudian diwujudkan melalui langkah-langkah yang lebih operasional. Beberapa langkah yang dirumuskan oleh 'Aisyyah Surabaya antara lain adalah pembentukan badan khusus, perekrutan dan pembinaan kader, pembentukan Pengawas Meminum Obat (PMO), pengadaan penyuluhan, pengadaan bantuan logistik untuk penderita TB, serta program kerjasama dengan pemerintah daerah. Karena program ini menyasar semua masyarakat Surabaya secara luas dan pengurus 'Aisyiyah Surabaya cukup terbatas, maka dalam pelaksanaannya 'Aisyiyah Surabaya tidak hanya mengandalkan pengurus dan anggota organisasi, tetapi nantinya juga melibatkan partisipasi masyarakat secara aktif. ${ }^{44}$

Langkah pertama 'Aisyiyah Surabaya adalah membentuk sebuah badan khusus, yaitu TB Care 'Aisyiyah. Badan ini berada di bawah majelis kesehatan 'Aisyiyah Surabaya, badan pembantu yang bergerak di bidang kesehatan. TB Care merupakan sebuah tim yang memiliki tiga pimpinan, yang terdiri dari seorang koordinator, kepala finance dan kepala data collection. ${ }^{45}$ TB Care 'Aisyiyah Surabaya ini lah yang menjadi koordinator lapangan untuk program "Surabaya Zero TB". Ketiga pimpinan TB Care 'Aisyiyah Surabaya bukanlah pengurus atau anggota 'Aisyiyah, tetapi ketiganya direkrut oleh 'Aisyiyah Surabaya secara profesional. Saat program-program

44 Alifah Hikmawati, Wawancara, Surabaya, 19 juni 2017.

45 Alifah Hikmawati, Wawancara, Surabaya, 9 Agustus 2017. 
berjalan, 'Aisyiyah Surabaya akan terus mengawasi kinerja TB Care, dimana 'Aisyiyah menunjuk salah satu pengurusnya untuk melakukan pengawasan. Secara rutin koordinator TB Care selalu memberikan laporan kinerjanya kepada perwakilan 'Aisyiyah Surabaya tersebut dan melakukan evaluasi, karena secara struktur keorganisasian pula, koordinator TB Care 'Aisyiyah tetap bertanggung jawab kepada ketua 'Aisyiyah Surabaya yang memberikan tugas. ${ }^{46}$

Langkah 'Aisyiyah Surabaya selanjutnya setelah membentuk TB Care adalah rekrutmen dan pendidikan/pembinaan kader. 'Aisyiyah Surabaya memberikan instruksi kepada Pimpinan Cabang 'Aisyiyah (PCA) agar membuka rekrutmen secara terbuka, artinya siapapun bisa menjadi kader untuk program pemberantasan TB, tidak hanya anggota maupun simpatisan 'Aisyiyah. ${ }^{47}$ Saat perekrutan, PCA menyampaikan bahwa TB merupakan masalah serius yang harus ditanggulangi, dan di Surabaya sendiri jumlah penderita TB tergolong tinggi, bahkan tertinggi di Jawa Timur.

Setelah adanya perekrutan, para kader akan diberikan pendidikan untuk bagaimana bekerja. Pendidikan tersebut sebagai bentuk persiapan sebelum turun ke lapangan melalui koordinasi TB Care. Hal yang akan dilakukan kader di lapangan nantinya mencari suspect TB baik itu dari kalangan muslim maupun nonmuslim, mengantarkan ke puskesmas

\footnotetext{
46 Ibid.

47 Ibid

48 "Sistem Pengkaderan Muhammadiyah", dalam: http:

//www.Muhammadiyah.or.id (8 september 2017)
}

serta melakukan pembinaan kepada keluarga penderita TB agar dapat merawat serta menangani penderita TB dengan benar.

Untuk mendorong keinginan dan kesadaran para kader dalam bergerak, 'Aisyiyah Surabaya juga mengikutkan semua pihak serta kader yang terlibat dalam program pemberantasan TB ke dalam baitul arqam. Baitul arqam adalah peneguhan ideologi Muhammadiyah yang dilakukan secara periodik dan dilaksanakan diawal periode kepengurusan organisasi. Dengan kata lain, baitul arqam merupakan upaya pengkaderan, dengan harapan kader-kader tersebut dapat menjadi kader dengan sebenar-benarnya Islam. ${ }^{48} \mathrm{Hal}$ tersebut sebagaimana visi 'Aisyiyah, bahwa yang menjadi tujuan perjuangan organisasi adalah menciptakan masyarakat Islam yang sebenarbenarnya/kafah. Artinya Islam tidak hanya hidup dalam ruang lingkup ritual atau bahkan simbol saja, tetapi Islam juga dihidupkan di segala ruang, termasuk dalam bidang kesehatan. ${ }^{49}$ Rata-rata ada 80 kader di masing-masing kecamatan yang bekerja secara total, semuanya adalah relawan yang merupakan perempuan muslim. Relawan tersebut semuanya bekerja bukan untuk mendapatkan kompensasi finansial. Semuanya bekerja secara sosial, sekalipun ada reward namun nilainya sangat sedikit. ${ }^{50}$

Untuk menunjang penyembuhan penderita TB, 'Aisyiyah melalui TB Care lantas membuat membentuk Pengawas Menelan Obat (PMO).

\footnotetext{
${ }^{49}$ Alifah Hikmawati, Wawancara, Surabaya, 9 Agustus 2017.

50 Ibid.
} 
Sehingga sebagian kader akan direkrut lagi untuk menjadi PMO yang bertugas mengawasi dan memberi support terhadap pasien/penderita TB agar terus meminum obat secara konsisten hingga sembuh total. Hal tersebut dianggap penting karena masa penyembuhan untuk penyakit TB sangat lama dengan minimal 6 bulan. ${ }^{51}$ Pihak yang direkrut menjadi PMO adalah keluarga, kerabat, atau bahkan teman dekat dari pasien TB. Rekrutmen terhadap kerabat dekat dilakukan untuk memudahkan pelayanan dan support kepada penderita TB karena para kader memiliki keterbatasan waktu untuk senantiasa berinteraksi dengan penderita TB.

Hal yang cukup menarik ketika rekrutmen PMO dilaksanakan adalah pihak keluarga dan kerabat dekat penderita TB diberikan motivasi tersebih dahulu sehingga memiliki dorongan yang kuat untuk berkontribusi sebagai PMO. Motivasi diberikan berupa materi yang berlandaskan ajaran Islam, yaitu berdakwah dan membantu orang lain yang sedang kesusahan merupakan anjuran dalam agama Islam, dan siapapun yang melaksanakannya akan ditinggikan derajatnya oleh Allah Swt. Kemudian secara berkala PMO senantiasa diberikan pembekalan ilmu melalui TB Care 'Aisyiyah, pembekalan yang diberikan tidak hanya berhubungan dengan bagaimana memberikan penanganan kepada penderita $T B$, tetapi juga mengenai bagaimana menjaga kebersihan lingkungan, menjaga gaya hidup tetap sehat, serta berbagai tindakan preventif lainnya agar terhindar dari penyakit TB.

${ }^{51}$ Siti Maslamah, Wawancara, Surabaya, 10 september 2017.

52 lbid.
Kemudian 'Aisyiyah juga membuat program pengadaan logistik berupa genteng kaca untuk rumah penderita TB. Hal tersebut dirasa perlu karena penderita TB harus terkena sinar matahari agar bakteri TB segera mati. Sehingga dengan genteng kaca di dalam rumah akan membantu penderita TB agar dapat terpapar sinar matahari dengan mudah. 52 Untuk meningkatkan upaya pencegahan, 'Aisyiyah Surabaya membuat program penyuluhan kepada masyarakat Surabaya yang dirasa sangat penting, karena 'Aisyiyah menemukan fakta bahwa ada pemahaman yang salah di masyarakat mengenai TB. Banyak masyarakat menganggap bahwa TB bukanlah penyakit menular, melainkan penyakit keturunan. Sehingga apabila kesalahpahaman ini tidak diluruskan maka penderita TB akan semakin banyak. ${ }^{53}$ Setelah memberikan kesadaran dan pengetahuan yang benar mengenai penyakit TB, para pengurus 'Aisyiyah kemudian juga memberikan keterampilan kepada masyarakat mengenai cara hidup sehat dan menjaga kebersihan lingkungan mulai dari etika meludah dan batuk, menjaga kamar mandi agar tetap kering, menjaga tingkat kelembapan rumah dan sebagainya. ${ }^{54}$

Setelah berbagai langkah/program sebagaimana dijelaskan di atas berjalan cukup baik, 'Aisyiyah pun kemudian mencoba untuk melakukan evaluasi. Dari hasil evaluasi tersebut kemudian 'Aisyiyah mencoba untuk semakin meningkatkan upaya mereka dalam

\footnotetext{
${ }^{53}$ Alifah Hikmawati, Wawancara, Surabaya, 9 Agustus 2017.

${ }^{54}$ Siti Maslamah, Wawancara, Surabaya, 10 september 2017.
} 
penanggulangan dan pencegahan TB di Surabaya. 'Aisyiyah Surabaya kemudian melakukan kerjasama dengan pemerintah kota melalui dinas kesehatan dan puskesmas. Puskesmas atau rumah sakit dijadikan sebagai pusat data untuk mencari suspect oleh para kader. Pihak puskesmas serta dinas kesehatan juga turut memberikan materi, motivasi ataupun pengalaman-pengalaman dalam menangani penyakit TB kepada kader saat berjalannya program pembinaan. Pihak dari dinas kesehatan sangat merasa terbantu, karena pemberantasan TB juga merupakan bagian dari tanggung jawab dinas kesehatan. ${ }^{55}$

'Aisyiyah Surabaya juga melakukan advokasi dengan mengajukan peraturan daerah untuk penanggulan TB di kota Surabaya sudah ditetapkan panitia khususnya dan naskah peraturan daerah tengah disusun dan dibahas di DPRD kota Surabaya. Proses penyusunan dan pembahasan peraturan daerah tersebut telah berjalan maksimal, dan dalam waktu dekat akan segera disahkan. ${ }^{56}$ Sebelumnya, 'Aisyiyah Surabaya telah berhasil melakukan advokasi dengan dikeluarkannya Peraturan Daerah Nomor 2 Kota Surabaya tentang Upaya Kesehatan. Keberadaan peraturan daerah (perda) tersebut mampu memudahkan 'Aisyiyah Surabaya dalam menanggulangi TB dari segi pendanaan. ${ }^{57}$

Langkah konkret yang 'Aisyiyah Surabaya tempuh dalam melakukan advokasi perda

\footnotetext{
$55 \mathrm{lbid}$.

56 "'Aisyiyah bersinergi dengan DPRD kota Surabaya berantas TB", dalam: http://www.pwmu.co (20 juni 2017).

57 Siti Maslamah, Wawancara, Surabaya, 26 Desember 2017.
}

tersebut adalah dengan melakukan audiensi bersama Sekretaris Komisi D DPRD Kota Surabaya pada kegiatan bertajuk "Educate CSO to Develop Proposal for Fundraising Workshop with Potential Donors of TB MDR Support Group" yang diadakan di Gedung Dakwah Muhammadiyah Kota Surabaya. ${ }^{58}$

Bahkan pada kegiatan yang juga dihadiri perwakilan Dinas Kesehatan Surabaya tersebut, Ketua PDA Surabaya juga memohon Sekertaris Komisi D DPRD Kota Surabaya untuk mengingatkan Wali Kota Surabaya Tri Risma Harini terkait hasil audiensi sebelumnya tentang usulan rumah singgah untuk penanggulangan $\mathrm{TB} .^{59}$

\section{Unsur-unsur Dakwah Bilhal 'Aisyiyah Surabaya}

\section{a. Subjek Dakwah}

'Aisyiyah Surabaya sebagai suatu organisasi mengambil posisi sebagai subjek dakwah dalam upaya penanggulangan dan pencegahan TB ini. Namun tentu subjek dakwah di sini tidak hanya dapat dilihat dari sisi 'Aisyiyah selaku organisasi, tetapi juga dapat dilihat dari para pimpinan ataupun pengurus dari ‘Aisyiyah Surabaya sendiri. Para pimpinan dan pengurus dapat dikatakan sebagai dai, karena mereka secara aktif menyampaikan informasi atau pesan dakwah kepada masyarakat dengan pendekatan bilhal melalui program penanggungalan TB. Para pimpinan dan pengurus ini kemudian mengorganisasikan dirinya dalam wadah

\footnotetext{
58 “'Aisyiyah bersinergi dengan DPRD kota Surabaya berantas TB", dalam: http://www.pwmu.co (20 juni 2017).

59 Ibid.
} 
organisasi 'Aisyiyah. Maka dapat disimpulkan bahwa subjek dakwah di sini adalah para pimpinan dan pengurus 'Aisyiyah Surabaya selaku dai maupun 'Aisyiyah Surabaya selaku kelembagaan atau organisasi dakwah.

Sebagai sebuah organisasi, banyak kegiatan 'Aisyiyah Surabaya yang menunjukkan bahwa mereka telah menekankan langkah nyata untuk menyelesaikan masalah yang ada di masyarakat. Mulai dari perekrutan dan pembinaan kader, pembentukan PMO, penyuluhan, pengadaan bantuan logistik untuk penderita TB, serta program kerjasama dengan pemerintah daerah; menunjukkan 'Aisyiyah Surabaya tidak hanya sebagai organisasi tetapi juga bisa disebut sebagai organisasi dakwah yang menjalankan upayaupaya dakwah bilhal.

\section{b. Objek/Mitra Dakwah}

Masyarakat yang menjadi objek/mitra dakwah dalam dakwah bilhal yang dilaksanakan oleh 'Aisyiyah Surabaya tergolong luas. Secara geografis dan demografis objek dakwah bilhal 'Aisyiyah Surabaya menyasar semua masyarakat kota di Surabaya, yang tidak terbatas oleh jenis pekerjaan, usia ataupun jenis kelamin. Semua pihak yang membutuhkan pertolongan karena wabah TB tentu akan dibantu oleh 'Aisyiyah Surabaya melalui program penanggulangan dan pencegahan TB ini. Bahkan yang paling menarik, umat nonmuslim juga menjadi objek dakwah bilhal 'Aisyiyah Surabaya. Hal ini tidak terlepas karena motivasi dakwah dari

${ }^{60}$ Alifah Hikmawati, Wawancara, Surabaya, 9 Agustus 2017.

61 "TOSS TB, Aisyiyah Surabaya Blusukan Berantas Tuberculosi", dalam shttp://klikmu.co/toss-tb-
'Aisyiyah Surabaya sendiri, dimana nilai-nilai kebenaran berdasarkan ajaran Islam harus disampaikan kepada umat tanpa terkecuali. ${ }^{60}$

Bahkan mitra dakwah 'Aisyiyah Surabaya semakin spesifik sesuai pada program yang dicanangkan, yakni gerakan Bersama 1-15. Suatu gerakan pendeteksian penularan TB dari satu penderita atau pasien kelimabelas rumah yang ada di sekitar penderita TB termasuk pemeriksaan dahak seluruh anggota keluarga pasien yang tinggal satu rumah dengan penderita. ${ }^{61}$ Sehingga mitra dakwah 'Aisyiyah Surabaya tidak terikat oleh ikatan kader, maupun kesamaan agama Islam semata, namun sejauh ia termasuk dalam lingkup lima belas rumah sekitar penderita TB, maka ia juga menjadi mitra dakwah 'Aisyiyah Surabaya.

Pada perkembangannya, mitradakwah ini juga menjadi subjek dakwah. Hal ini karena program penanggulangan dan pencegahan TB oleh 'Aisyiyah Surabaya bersifat partisipatif dalam pelaksanaaannya, sehingga masyarakat pun turut dilibatkan secara aktif untuk menjalankan program tersebut. Masyarakat juga turut didorong untuk memiliki kesadaran akan bahaya wabah TB sehingga harus aktif dalam menanggulangi dan mencegah. ${ }^{62}$

\section{c. Pesan Dakwah}

'Aisyiyah Surabaya yang memiliki tujuan menciptakan masyarakat Islam yang kafah/Islam yang sebenar-benarnya tentu memiliki pesan tersendiri yang hendak

aisyiyah-surabaya-blusukan-berantastuberculosis/ (1 Juli 2018).

$62 \mathrm{lbid}$. 
disampaikan melalui dakwah bilhalnya ini. Pesan yang paling utama tentu terkait dengan masalah kesehatan yang banyak tidak disadari oleh masyarakat. Dalam forum penyuluhan dan pembekalan PMO pesan itu banyak disampaikan, tentang bagaimana bahaya wabah TB dan bagaimana TB disembuhkan dan dicegah. Selain itu, dengan tindakantindakan nyata yang dilakukan oleh pengurus 'Aisyiyah, pesan yang hendak disampaikan adalah mengenai kepedulian sosial, artinya Islam yang kafah tidak hanya sebatas ibadah atau ritual kepada Tuhan tetapi juga mengajarkan bagaimana hidup bermasyarakat dan ada rasa peduli. ${ }^{63}$

Pesan ini secara langsung juga disampaikan melalui darul arqam. Maka dapat disimpulkan bahwa pesan dakwah yang disampaikan oleh 'Aisyiyah Surabaya dalam dakwah bilhalnya cenderung tidak menyangkut masalah akidah dan syariat, melainkan lebih menyangkut masalah sosial kemasyarakatan dan akhlak. Masalah sosial kemasyarakatan yang dimaksud adalah pemecahan masalah kesehatan di masyarakat, dalam hal ini adalah pencegahan dan penanganan penyakit TB di masyarakat sekitar lingkungan organisasi dakwah. Hal ini sekaligus menyiratkan pesan bahwa Islam peduli masalah kesehatan, Islam peduli dengan keadaan masyarakat sekitar, dan Islam peduli dengan melakukan tindakan nyata. Sedangkan masalah akhlak yang dimaksud di antaranya pesan untuk berperilaku hidup sehat dan menjaga kesehatan agar terhindar dari TB, serta

63 Ibid. perilaku penanganan terhadap masalah TB di masyarakat.

\section{d. Metode Dakwah}

Metode yang digunakan oleh 'Aisyiyah Surabaya dalam dakwah bilhalnya tetap dengan hikmah, hal ini karena objek dakwahnya tidak hanya dari umat muslim tetapi juga nonmuslim, sehingga tidak ada satu pun yang merasa terpaksa atau keberatan. Hal ini terlihat dari penyampaian pesan yang banyak menggunakan pendekatan ilmu pengetahuan, misalnya ilmu kesehatan yang relatif lebih mudah untuk diterima. Pesan-pesan dakwah itu disampaikan dengan melalui pendidikan secara informal, yakni dengan penyuluhan kepada masyarakat, juga pembekalan yang diberikan kepada caloncalon kader TB Care ataupun calon PMO. ${ }^{64}$ Selain itu, metode dakwah yang dilakukan adalah melalui tindakan nyata pengurus 'Aisyiyah yang terjun ke lapangan dengan menjadi pendamping, dan pengawas menelan obat di masyarakat. Tindakan nyata tersebut sekaligus sebagai wujud teladan bagi masyarakat agar memiliki kepedulian terhadap masalah masyarakat.

\section{e. Media Dakwah}

Karena dakwah bilhal 'Aisyiyah sangat menekankan penyelesaian masalah riel yang spesifik di masyarakat kota Surabaya, maka dalam setiap forum (penyuluhan dan pembekalan) media yang digunakan adalah media nonmassa seperti proyektor, papan pengumuman, gambar/foto, internet. Logistik berupa genteng kaca yang diberikan kepada

${ }^{64}$ Siti Maslamah, Wawancara, Surabaya, 10 september 2017. 
penderita TB juga dapat dikatakan sebagai media karena sifatnya juga mendukung berjalannya program dan diterimanya pesan dakwah oleh masyarakat.

\section{Prinsip Pelaksanaan Dakwah Bilhal} 'Aisyiyah Surabaya dalam Penanggulangan dan Pencegahan TB

Berdasarkan paparan sebelumnya dapat diambil kesimpulan bahwa apa yang perjuangkan 'Aisyiyah Surabaya tersebut sebagaimana hakekat dari dakwah bilhal yang menekankan adanya perbaikan pada masalah-masalah masyarakat. Harun AlRasyid menekankan bahwa dakwah bilhal harus dipahami secara luas dengan adanya berbagai program perbaikan di berbagai sektor masyarakat, ${ }^{65}$ dan di sini 'Aisyiyah Surabaya mengambil peran penting untuk memperbaiki kualitas hidup masyarakat dari sisi sektor kesehatan.

Tidak hanya itu, dakwah bilhal yang dilaksanakan oleh 'Aisyiyah Surabaya juga tidak menghilangkan dakwah lisan yang sudah dulu dilaksanakan melalui badan pembantu majelis tablig. Oleh karena itu, dakwah bilhal tetap didudukkan sebagai pendukung dakwah lisan. Dengan kata lain, dakwah bilhal yang dilaksanakan semakin menguatkan secara kesuluruhan program-program dakwah yang dilaksanakan oleh 'Aisyiyah Surabaya.

Dalam penerapannya, maka setidaknya ada beberapa hal yang dapat dijelaskan bagaimana upaya penanggulangan dan pencegahan TB oleh 'Aisyiyah Surabaya yang merupakan serangkaian dakwah bilhal yang berorentasi perbaikan masalah masyarakat melalui prinsip-prinsip sebagai berikut:

\section{a. Mengajak umat memahami masalah}

Upaya ini dilakukan oleh 'Aisyiyah Surabaya saat awal kali program penanggulangan dan pemberantasan TB dijalankan, yaitu yang direkrut oleh 'Aisyiyah untuk menjadi kader/relawan adalah masyarakat secara luas, maka ketika melakukan perekrutan para pimpinan 'Aisyiyah sudah memberikan pemahaman akan masalah yang ditengah dihadapi terkait dengan wabah penyakit TB. Begitu pula saat 'Aisyiyah mengadakan penyuluhan ke beberapa tempat, para pimpinan berupaya untuk memberikan informasi yang benar ke masyarakat mengenai masalah TB. Saat 'Aisyiyah mencoba untuk melibatkan keluarga dan kerabat dekat penderita TB sebagai PMO pun sebetulnya hal itu juga upaya agar masyarakat lebih menyadari akan masalah wabah TB, tentu dengan harapan agar masyarakat mau bergerak sehingga upaya pencegahan lebih berjalan efektif. Namun yang paling terpenting pada tahap ini adalah 'Aisyiyah Surabaya telah memperbaiki pengetahuan yang salah dan menyadarkan masyarakat, bahwa penyakit TB dapat disembuhkan dan dapat dilakukan pencegahan.

Dengan memberikan pemahaman yang benar dan masyarakat telah memahami apa yang menjadi masalahnya, maka untuk selanjutnya 'Aisyiyah Surabaya berupaya untuk mengorganisir dan melibatkan masyarakat untuk menyelesaikan masalah tersebut. Hal

${ }^{65}$ Al-Rasyid dkk, Pedcman., 10-14. 
ini dapat dlihat pada bagaimana partisipasi masyarakat pada berbagai langkahlangkah/program 'Aisyiyah dalam menanggulangi TB sebagaimana telah dijelaskan sebelumnya.

\section{b. Menumbuhkan keinginan}

\section{umat/masyarakat untuk berperan aktif.}

Setelah masyarakat memahami apa yang menjadi masalahnya dengan benar terkait dengan wabah TB, maka langkah selanjutnya yang dilakukan adalah bagaimana agar masyarakat juga turut berperan aktif dalam penanggulangan dan pencegahan TB. Upaya pada tahap ini dapat terlihat jelas pada baitul arqam. Forum tersebut adalah upaya untuk memotivasi masyarakat yang direkrut menjadi kader agar mereka termotivasi untuk bergerak. Namun yang menjadi catatan penting adalah motivasi tersebut lebih didorong oleh nilai-nilai yang bersifat ideologis. Oleh karena itu, sejatinya masyarakat bukan hanya tumbuh keinginannya, namun juga memiliki motivasi yang sangat kuat. Motivasi tersebut tentu dilandasasi oleh nilai nilai Islam. Begitu pula saat 'Aisyiyah merekrut keluarga dan kerabat dekat untuk menjadi PMO, dalam forumforum pelatihan pihak keluarga dan kerabat sebelum dilibatkan juga diberikan pemahaman yang bersifat nilai-nilai yang bersumber dari ajaran Islam, sehingga atas dasar itulah pihak keluarga dan kerabat dekat penderita TB juga mau untuk ikut berperan dalam penanggulangan TB serta pencegahan TB. Sehingga tidak semata-mata karena ingin membantu keluarga atau kerabat dekatnya.

${ }^{66}$ Alifah Hikmawati, Wawancara, Surabaya, 9 Agustus 2017.
Hal yang perlu menjadi catatan pada prinsip ini adalah bagaimana 'Aisyiyah Surabaya melibatkan masyarakat dalam mencari alternatif solusi. Sejauh ini solusi-solusi yang diambil untuk memecahkan masalah masih bergantung pada pimpinan 'Aisyiyah Surabaya selaku dai, yang kemudian solusi tersebut diimplementasikan dalam program 'Aisyiyah Surabaya beserta langkah-langkah konkretnya sebagai upaya penanggulangan dan pemberantasan TB. Akan tetapi, 'Aisyiyah Surabaya akan terus mengembangkan program dakwah bilhal-nya, sehingga lebih bersifat partisipatif dalam perumusan kebijakan atau program nantinya akan dimungkinkan untuk diterapkan. ${ }^{66}$

\section{c. Perlibatan umat/masyarakat dalam pelaksanaan pemecahan masalah}

Sejak program "Surabaya Zero TB" ditetapkan, 'Aisyiyah Surabaya langsung memutuskan bahwa untuk pelaksanaannya maka umat/masyarakat harus dilibatkan. Hal paling prinsip dalam perlibatan umat tersebut adalah para koordinator TB Care 'Aisyiyah yang direkrut berasal dari masyarakat umum karena 'Aisyiyah Surabaya melakukan rekutmen secara terbuka. Begitu pula dengan rekrutmen kader atau relawan yang dilakukan, semuanya juga bersifat terbuka. Oleh karenanya, kader-kader atau relawan yang terlibat dalam penanggulangan dan pencegahan TB bersifat lebih "cair", artinya tidak hanya berasal dari anggota atau simpatisan 'Aisyiyah, tetapi juga berasal dari orang-orang yang bahkan belum mengenal 
'Aisyiyah. ${ }^{67}$ Hal yang sama pun juga terjadi saat 'Aisyiyah Surabaya merekrut PMO, pihak keluarga dan kerabat dekat penderita TB yang dilibatkan tidak sedikit yang belum mengenal 'Aisyiyah Sebelumnya.

Maka dapat disimpulkan bahwa perlibatan umat/masyarakat dalam pelaksanaan dakwah bilhal-nya sudah dilaksanakan oleh 'Aisyiyah Surabaya secara keseluruhan melalui program beserta langkah-langkah konkretnya.

\section{d. Penyebarluasan Metode-Metode Swadaya Umat}

Upaya menyebarluaskan metode-metode swadaya umat dalam hal penanggulangan dan pencegahan TB agar masyarakat dapat mandiri sudah dirancang dengan cukup spesifik oleh 'Aisyiyah Surabaya. Upaya ini terlihat dengan adanya upaya mendidik masyarakat oleh 'Aisyiyah Surabaya. Adanya program penyuluhan merupakan upaya 'Aisyiyah agar masyarakat dapat secara mandiri menjaga lingkungan dan kesehatan mereka secara mandiri agar terhindar dari penyakit TB. Begitu pula dengan pembekalan ilmu yang diberikan kepada PMO penderita TB, mereka secara khusus diberikan keterampilan bagaimana menangani penderita TB dan juga keterampilan dalam hal pencegahan penyakit TB. Tidak hanya itu, dalam forum pembekalan tersebut PMO juga dimotivasi agar menyebarkan apa yang

$67 \mathrm{lbid}$.

68 Siti Maslamah, Wawancara, Surabaya, 26 Desember 2017.

69 Ibid.

${ }^{70}$ Alifah Hikmawati, Wawancara, Surabaya, 9 Agustus 2017.

${ }^{71}$ Siti Maslamah, Wawancara, Surabaya, 26 Desember 2017. Lihat juga: "'Aisyiyah bersinergi dengan DPRD kota mereka dapatkan ke anggota masyarakat yang lain. ${ }^{68}$ Motivasi diberikan melalui pendekatan nilai-nilai keagamaan Islam yang disampaikan oleh pengurus dari TB Care 'Aisyiyah. ${ }^{69}$

\section{e. Evaluasi dan Tindak Lanjut}

Evaluasi terhadap pelaksanaan program "Surabaya Zero TB" selalu dilaksanakan secara berkala yang melibatkan Pimpinan 'Aisyiyah Surabaya" serta TB Care 'Aisyiyah. Hasil dari evaluasi pelaksanaan menunjukkan hasil positif, yang kemudian mendorong 'Aisyiyah Surabaya untuk melakukan advokasi sebagai tindak lanjutnya. Menurut pimpinan 'Aisyiyah Surabaya perjuangan pencegahan TB harus dilakukan dalam lingkup yang lebih luas dengan memperjuangkan peraturan perundang-undangannya yang melibatkan pihak pemerintah. 70 Advokasi yang diperjuangkan oleh pimpinan 'Aisyiyah Surabaya kemudian membuahkan hasil dengan disahkannya Peraturan Daerah Kota Surabaya Nomor 2 Tahun 2017 tentang Upaya Kesehatan. ${ }^{71}$ Dengan adanya peraturan daerah ini 'Aisyiyah Surabaya mendapatkan kemudahan pendanaan dalam menjalankan program kesehatannya untuk menanggulangi dan mencegah TB. ${ }^{72}$

Maka dapat disimpulkan bahwa dakwah bilhal melalui upaya penanggulangan dan pencegahan TB oleh 'Aisyiyah Surabaya telah dilakukan secara berkesinambungan untuk

Surabaya berantas TB", dalam: https://pwmu.co/21618/12/23/aisyiyah-bersinergidengan-dprd-untuk-wujudkan-surabaya-bebas-tb/ (20 juni 2017)

72 Siti Maslamah, Wawancara, Surabaya, 26 Desember 2017. 
mencapai hasil maksimal dengan adanya evaluasi dan tindak lanjut. Proses evaluasi dan tindak lanjut ini tetap melibatkan pimpinan 'Aisyiyah sebagai dai dan pihak TB Care sebagai perwakilan dari umat/masyarakat sebagai wujud partisipasi.

\section{Kesimpulan}

'Aisiyah Surabaya selaku organisasi dakwah beserta pimpinan dan pengurusnya merupakan subjek dakwah bilhal melalui program penanggulangan dan pencegahan TB dengan mad'uw yang sangat luas pada masyarakat kota Surabaya, khususnya penderita TB serta masyarakat sekitarnya. Dakwah bilhal ini dilaksanakan dengan metode hikmah dengan pesan-pesan dakwah yang syarat akan kepedulian sosial dan nilainilai kebenaran yang menyangkut masalah sosial kemasyarakatan, khususnya masalah kesehatan. Dakwah bilhal ini juga didukung dengan media-media dakwah yang dirasa cukup efektif dan efisien dengan pengadaan forum-forum yang langsung menyentuh masyarakat.

Dakwah bilhal yang dilaksanakan oleh 'Aisyiyah Surabaya tidak menghilangkan dakwah lisan yang sudah dulu dilaksanakan, karena kedudukan dakwah bilhal yang dilakukan tetap untuk melengkapi dakwah lisan. Kemudian melalui program "Surabaya Zero TB", dakwah bilhal "Aisyiyah Surabaya mengajak umat memahami masalah dengan memberikan informasi yang benar mengenai penyakit TB lewat beberapa media dan program, menumbuhkan keinginan umat untuk berperan aktif dengan motivasimotivasi kegamaan yang disampaikan oleh pimpinan 'Aisyiyah, melibatkan umat dalam pelaksanaan pemecahan masalah dengan merekrut masyarakat sebagai kader/relawan serta PMO, menyebarkan metode-metode swadaya umat dengan pendidikan/pembekalan yang diberikan mengenai pengobatan dan pencegahan TB dan adanya evaluasi dan tindak lanjut yang melibatkan umat pula dengan advokasi yang diperjuangkan 'Aisyiyah Surabaya. Hal yang perlu ditingkatkan adalah pada bagaimana untuk meningkatkan lagi partisipasi masyarakat, khususnya pada pengambilan keputusan di tengah berbagai alternatif solusi pemecahan masalah yang kemudian direalisasikan pada perumusan program atau kebijakan.

Bagi organisasi dakwah yang saat ini berkembang, dakwah bilhal oleh 'Aisyiyah Surabaya ini tentu dapat menjadi contoh untuk pengembangan dakwah yang tidak hanya mengandalkan lisan. Dakwah bilhal yang dilaksanakan tentu harus tepat sasaran, sesuai dengan kebutuhan atau permasalahan yang ada di masyarakat, serta sebisa mungkin melibatkan partisipasi masyarakat agar dakwah bilhal lebih baik lagi dan dapat dilaksanakan dalam skala luas. Di samping itu, sebagai usaha pengembangan keilmuan terkait dakwah bilhal yang melibatkan suatu organisasi dakwah, maka untuk kedepannya diharapkan ada kajian-kajian yang lebih meneliti dakwah bilhal yang diterapkan dalam sektor yang selainnya. 'Aisyiyah Surabaya sendiri memiliki beberapa majelis/badan pembantu yang bergerak di berbagai bidang mulai dari pendidikan, ekonomi, kesejahteraan masyarakat, hukum, budaya dan sebagainya. Berbagai majelis/badan 
pembantu tersebut memiliki program masingmasing yang menyentuh masyarakat secara langsung. Hal itu tentu merupakan kesempatan bagi peneliti-peneliti selanjutnya untuk mengembangkan keilmuan dakwah bilhal.

\section{Bibliografi}

Ahmad, Amrullah. Dakwah Islam dan Perubahan Sosial. Yogyakarta: PLP2M, 1985.

Aisyiyah, "Visi Misi 'Aisyiyah Surabaya", dalam: http://aisyiyahsurabaya.sg, diakses pada 20 juni 2017

Amin, Samsul Munir. Ilmu Dakwah. Jakarta: Amzah, 2009.

Amin, Samsul Munir. Ilmu Dakwah. Jakarta: Amzah, 2013.

Aziz, Moh. Ali. Ilmu Dakwah. Jakarta: Kencana, 2004.

Al-Rasyid, Harun dkk. Pedcman Pemtrinaan Dakwah Bil-Hal. Jakarta: Depag RI, 1989.

Dahlan, Adaby. 'Aisyiyah dan Sejarah Pergerakan Perempuan Indonesia: Sebuah Tinjauan Awal. Yogyakarta :Jurusan Sejarah FIB UGM, 2010.

Faizal, "Dakwah Bil-Hal dalam perspektif al-Qur'an", Jurnal Ilmu Dakwah dan Pengembangan Komunitas, Vol. VIII No. 2 Juli 2013.

Ilaihi, Wahyu. Komunikasi Dakwah. Bandung: Remaja Rosdakarya, 2010.

KlikMU, "TOSS TB, Aisyiyah Surabaya Blusukan Berantas Tuberculosi", dalam shttp://klikmu.co/tosstb-aisyiyah-surabaya-blusukan-berantas-tuberculosis/, diakses pada 1 Juli 2018

Mubarok, Achmat. Psikologi Dakwah. Jakarta: Prenada media, 2006.

Muhammadiyah, "Sistem Pengkaderan Muhammadiyah", dalam: http: //www.Muhammadiyah.or.id, diakses pada 20 juni 2017

Mu'minin, A. Syaiful. "Konstruksi Simbolik Dakwah Bilhal dalam Film Hafalan Shalat Delisa", Skripsi - UIN Syarif Hidayatullah, 2014

Munir, dkk. Metode Dakwah. Jakarta: Kencana, 2009.

Muru'ah, Siti. Metodologi Dakwah Kontemporer. Yogyakarta: Mitra Pustaka, 2000.

Nasir, Haedar. Islam dan Prilaku Umat di Tengah Perubahan. Yogyakarta: Pustaka SM, 2002.

Nugroho, Sumarno. Sistem Intcrvensi Kesejahteraan Sosial. Yogyakarta: Hanindila, 1984.

Patiminingsih, Astuti. "Strategi Dakwah 'Aisyiyah Dalam Pembinaan Keluarga Sakinah", Jurnal Ilmu Dakwah dan Pengembangan Komunitas, Vol. 9, No. 2, Juli, 2014.

PWM Jawa Timur, "Aisyiyah Gugah Pemkot untuk Surabaya Bebas HIV dan TB", dalam: http://www.pwmu.co, diakses pada 9 september 2017

PWM Jawa Timur, "'Aisyiyah bersinergi dengan DPRD kota Surabaya berantas TB", dalam: http://www.pwmu.co, diakses pada 9 september 2017

Saputra, Wahidin. Pengantar Ilmu Dakwah. Jakarta: Raja Gafindo Persada, 2012.

Satori, Djam'an. Metode Penelitian Kualitatif. Bandung: Alfabeta, 2010.

Shadily, Hasan dan Jonh M. Echols. 2000. Kamus Inggris Indonesia. Jakarta: Gramedia.

Shihab, Quraish. Membumikan Al-Qur'an. Bandung: Mizan, 1994. 
Sugiyono. Metode Penelitian Kuantitatif Kualitatif Dan R \& D. Bandung: Alfabeta, 2008.

Suisyanto. "Dakwah Bil-Hal (Suatu Upaya Menumbuhkan Kesadaran dan Mengembangkan Kemampuan Jemaah)", Aplikasia, Jurnal Aplikasi IImu-ilmu Agama. Vol. III, No. 2 Desember 2002.

Sumarlik, "Aktifitas Organisasi 'Aisyiyah Cabang Wonocolo terhadap Pembinaan Keluarga Sakinah di Kecamatan Wonocolo Kodya Surabaya," Tesis - UIN Sunan Ampel, Surabaya, 2016.

Sutoro, Eko. Reformasi Politik dan Pemberdayaan Masyarakat. Yogyakarta: APMD Press, 2004.

Syukir, Asmuni. Dasar-Dasar Strategi Islam. Surabaya: Al Ikhlas, 1983.

Syahputra, Chandra. "Pengaruh Metode Dakwah Bilhal terhadap Pembinaan Akhlak Remaja Gampong Maurendeh Kecamatan Langsa Lama”, Skripsi - STAIN Zawiyah Cot Kala Langsa, 2013.

Tribunnews. "30 Kader 'Aisyiyah Surabaya Ketuk 1000 Rumah Warga Surabaya", dalam: http://jatim.tribunnews.com

Umam, Khoirul. "Visualisasi dakwah bilhal dalam film Alangkah Lucunya Negeri Ini”, Thesis - UIN Walisongo, 2016.

Wirosardjono, Soetjipto. "Dakwah: Potensi dalam Kesenjangan" dalam Majalah Pesantren, No. 4 Vol. IV (Jakarta: P3M, 1987) 